\title{
Aspects of Private Labels Development in the Segment of Organic Food in Czech Republic
}

Submitted: November $5^{\text {th }}, 2009$

Accepted: January 29th 2010

\section{Summary}

The article deals with various aspects of the private labels building. It primarily focuses on organic food market in the Czech Republic, but on this market it illustrates the general trends, both in brand building, as well as in the importance of a brand in purchasing decisions.

Organic food market is specific as there is high importance of product attributes, which are based on customer's confidence. Many of the important criteria for the decision to purchase (the way of cultivation and processing of food, freshness, taste, etc.) are not possible to be objectively assessed before buying.

A brand name plays a large role in the confidence based attributes. Consumers perceive it as a certain guarantee of the expected quality. In the field of organic food there are still not strong brands but there is the space and the need to differentiate organic from conventional foods, in particular. A suitable option could be the retail chain private labels, which are already partially developed as far as for consumers subconscious expectations are concerned.

The final part of the article provides an overview of the current offer of organic food private labels in the Czech Republic.

\section{Introduction}

In the period of economic recession companies should not only try to outlast it with as few losses as possible. This period is the best era to plan and prepare further

* M.Sc., Institute of Chemical Technology, Prague, the Czech Republic.

** Ph.D., Institute of Chemical Technology, Prague, the Czech Republic.

${ }^{1}$ This article is published as the part of research intention MSM 6046137306. 
development, because each recession period is followed by an increase of economy. Therefore recession is suitable not only for training of key staff, general reconstruction and improvement of production equipment, but also for creating a strategy for further development.

For the company it is important to move the customer to buy its products. Customers have to perceive the value of a certain goods and be able to identify them among other products. Brand is one of the most important factors which help the identification. Perception of value is a complex process that it is possible affected by many factors and may find it for the producers and the consumers perceive the same product differently. If this difference really exists, it must be identified and taken into account in formulating the strategy.

In this article we will focus on various aspects of brand building on the Czech organic products market, particularly with regard to the creation and development of private labels. It is still a small market but it has a high potential, and therefore it is useful to know how consumers perceive the value of organic products and if there already exist enough strong brands to be identified by individual producers.

\section{The organic food market in the Czech Republic}

The increasing attention is paid to issues related to the negative impact of human activities on the environment not only in the Czech Republic but also at global level in recent years. The principles of the organic food production and manufacture ensure compliance with environmental principles throughout the course of treatment, compared with conventional procedures reduce the disproportionate burden on the environment and last but not least organic food positively affect the health of consumers, so they gradually get more and more supporters.

Figure 1.

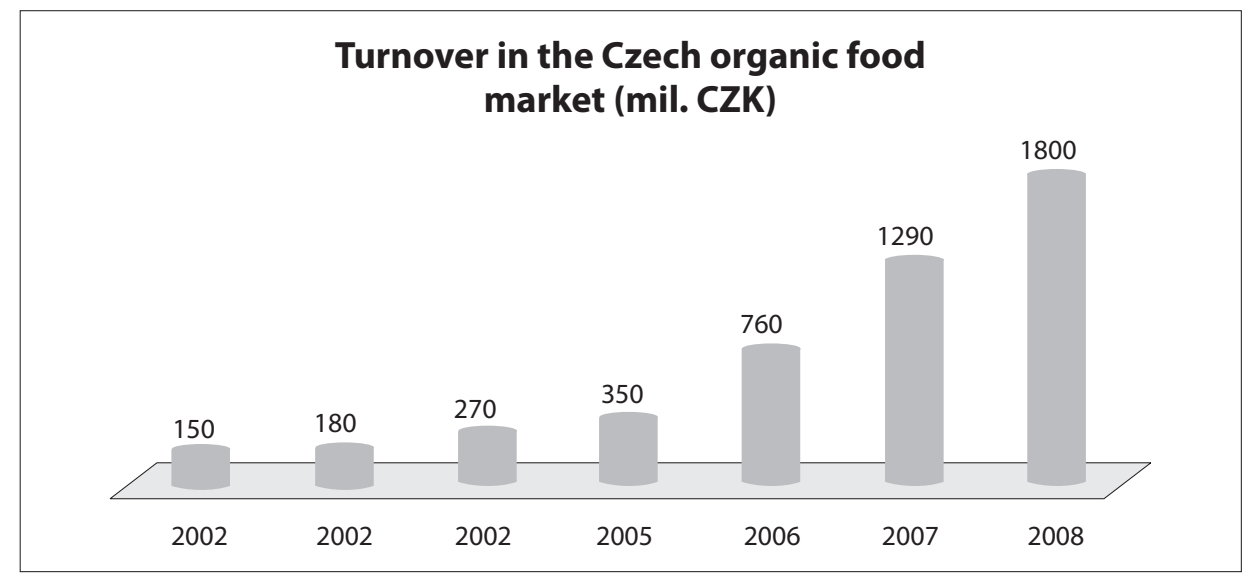

Source: http://www.mze.cz 
Increasing share of the organic food in total consumption is surely one of the most important trends that may be identifying in the food industry nowadays. The market of organic product in the Czech Republic is a relatively young market, first mentioned in 1990, when the first 3 organic farms rised. Since this time turnover has grown every year and the Czech organic food market has become with the retail turnover of 1.29 billion CZK the fastest growing European organic food market in 2007. In the Czech Republic is registered a total of 2586 subjects farming organically nowadays (http://www.mze.cz/).

The following graph illustrates the development of the turnover of the Czech organic food market in the years 2002-2008 and there is apparent a significant increase due to rising volumes of food imported from abroad and the rising share of the home organic food production too.

Although the development of the Czech organic food market follows the trend in Western European countries and USA (Onyango, 2007), the share of organic food in total food consumption still remains over consumption in Western Europe at a relatively low level. The most sales have traditionally been involved in cereals and milk and beef meat.

\section{The specifics of the organic food products communication}

Organic products represent the specifics products' category from the perspective of communication with a consumer. Model of consumer behaviour presents relationships between presumptions to specifics of consumer behaviour, between stimuli, which starts specific consumer behaviour, between course of the decision-making process of consumers and the final results of the process (Koudelka, 1997).

Communication is counted among significant external factors of the model. To push a communication strategy, the classification parameters of quality of the product based on the theory of economics of information is important (Nelson, 1970).

According to the theory attributes of the product can be divided into following dimensions:

1. Much-sought-for: the consumer can make himself sure about the attribute on purchase,

2. Verifying: the consumer can check the attribute after purchase, by using the product,

3. Based on the confidence: the common consumer does not know how to appreciate the attribute by the objective methods as for example tasting, the only possibility is to trust to the declarations of the producer, the distributor, the trader, the independent organization, etc.

In thoses cases, where the difference in the similar products is based on the specific origin or on the specific process of the production, the importance of the attributes based on the confidence increases. The customer is not able to appreciate the quality directly, he or she only makes up some expectations based on the parameters, which are connected with the product. The parameters are for example the design of the product, color, shape, price, place of sale etc., the importace of the parameters is individual and doesn't relate only with the natur of the product but also with the charakter of the consumer. The other 
way, how the expectation can be created, is based on the previous experience with using the product, provided that the product can be identified for example by means of the name of brand. In the bioproducts market customers usually are not able to find out objective proofs, which make an appreciation of attributes, relating to processes of production and relating to the impact on the human health, possible. The conviction of existence of the attributes is based on the customers' confidence and therefore is necessary to make a trustworthy communication (Grosová, 2004).

The effect of a trustworthy source of information on the persuasiveness on the example of organically produced food was empirically demonstrated. In the case that a trusted entity is responsible for fact that the food with the mark BIO has actually been produced according to certain principles of organic agriculture consumers accept this fact and for the subsequent showed their activities leading to complement and extend information related to this products' group (Grunert, 1996). These facts indicate that the marketing of specific food products such as organic food products that provide consumers benefits based primarily on the trust in their existence, can be successful if it is supported by strong brands. Strong brand, evoking the feeling of the confidence and of the reliability in the connection with the ways of distribution and with the provided services, can greatly contribute to the successful expansion of these products on the market (Grosová, 2004).

\section{Creating and strategic brand management}

The brand is according to the American Marketing Association defined as "name, term, sign, symbol or design or combination thereof, which are designed to identify the goods or services of one seller or group of sellers and to differentiate them from goods or services of competitors (Vysekalová, 2004: 132).

"Brand was originally symbolized quality, but today is more evidence of social level to its bearer" (Kleinová, 2005: 23).

„Brand is a symbol created by a technical written or spoken word, images, graphs, etc.; its function is to differentiate, to identificate, to defense and to promote" (Homola, 1992: 21).

Creation, successful implementation and strategic brand management is a difficult and long process, at the end, if it is successful, is strong brand that offers their owners a substantial number of advantages:

- brand uniquely identify the originator of the product,

- consumers recognize the brand through the past experience with the product and its marketing program,

- consumers can evaluace the same product with the different brands completely differently,

- brand simplify the decision-making process,

- brand reduce the risk of the consumer,

- brand indicate a certain level of quality and increase customer loyalty,

- for the company the brand becomes a hot property. 
The main assumption for successful brand building is a consumers' belief that there are meaningful differences among individual brands in the market. These differences could by associate not only with the specific characteristics of products but also created whereby means that are not related directly to the product and rely more on understanding the needs and motives of consumers.

Customers expected strong brand is able to offer some value. According to various authors (Loštáková and Jelínková, 2008; Kotler, 2000; Keller, 2007) there are differences in the view to definition of value. In principle they agree that the value of customer is difference between benefits, which he obtains thanks to he can possess and use the product and the effort, which he has to spend to obtain the product. Therefore it is important be seen from a customer standpoint (Bohuněk, 2009).

Almost all consumers can be under certain conditions divided (it is necessary to pay attention to branch) accordingly their individual attitudes to brand (De Pelsmacker, 2003):

- a deprecation of the brand - consumer wants the product, but he does not want the brand in any case (it can be negative association to connection with brand, e.g. "snobbery"),

- indiscrimination of the brands - consumer does not discriminate between branded and not-branded goods, he does not care or he deprecates doing differences; there are other aspects in decision making process (e.g. price),

- a perception of the brand - consumer distinguishes among the products by means of the brands, but usually he is influenced by other aspects (e.g. Sony, it will be expensive),

- a preferention of the brand - a brand is the main factor to buy individual product, but if he has not the favoured brand to disposal, he is ready to buy another product, sometimes a non-branded product, too,

- an insistence of the brand - this attitude is very favourable for the producer because customer insist branded product and is not willing to buy another one, if the brand is not in disposal.

It is possible to say, that brand value offer is something like announcement about functional, emotional and self-realization benefits, which the brand brings to customer and gives him some value (Orth, 2004; Loštáková and Jelínková, 2008). Classification by these benefits characteristics is very difficult for organic food, because the nature of the products consists of several closely interconnected components. If the food is certified as an organic product, it means that in the entire process of its creation and processing there were used only natural materials, animals experienced their life in a welfare, agriculture was operated sound nature and in accordance with sustainable development principles and production processes (cultivation, processing, sale) do not damage environment and bring profit not only to the producer but the whole society.

The perception of benefits that the brand is able to provide the consumer is closely related to the price. Although the relationship between perceived quality and price of the product is complex and cannot be a priori generalized (Fauld, 1994), for most consumer, the price is usually the decisive factor in purchase. Padel and Foster (2005) found, that higher prices are sometimes barriers to purchasing organic food as well as their availability and poorer eating habits of consumers. In some cases higher price may 
indicate higher quality and offer greater value, but sometimes higher price decreases the value. Brand building should always be focused more on benefits than on price. People who are willing to pay for the bio have also more interested in the brand than those, who are not willing to pay more. This claim is true only for those products which are wellknown brands. For fresh fruit, raw meat does not look like the brand (Krystallis, 2005).

The basis for the offer brand values are the functional benefits - benefits, based on product attributes, which the customer can clearly use. These benefits usually closely linked directly with product function and are directly associated with the purchase decision and the customer's experience. Therefore it is important that the company chose the right functional benefit, which is most attractive for the customer and enable to reinforce the brand position in relation to the competition. Organic food consumers include the functional benefits mainly sensory characteristics and the other characteristics such as shape, taste, smell, size and overall feel of the product. However, consumer is not able to find difference between conventional and bio-product and therefore expects some assurance, e.g. certification.

It seems that the most appropriate method for assessing relative importance of product attributes is currently conjoint analysis.

To create a successful brand it is, after finding the optimal functional benefits, to choose the appropriate communication mix, which conveys in an effective way the existence of these benefits to customer.

The following dimensions of brand's value are emotional benefits. They reflect the fact, that the purchase or use of the brand gives the good impression and add importance and depth to experiences with the brand. If it is possible to find and formulate to customer emotional benefits connected with individual brand, the brand value is enriched of other assets. Relevant benefits for organic products in emotional sphere is linked both with perception of the product in the context of socio-economic complex and the environmental context. They are associated with health and safety, they are words such as clean, natural, with no genetic modification and production with low inputs. Other aspects of perception in terms of emotional benefits are associated with ethical aspects of production and processing, such as fair trade, positive impacts on the economy of developing countries, promotion of regional economies and animal welfare.

More and more customers use brands and products as well as symbols of personal expression. They express their vision of itself through purchase and using individual brand (Parker, 2009). If the brand can offer some self-expression benefit, it is very likely to consolidate the relationship and the consumer becomes a random loyal customer. Even for organic food, the desire to achieve some sort of exclusivity or the attempt to identify with a certain type of consumer, or vice versa, from a particular type distancing, can play a considerable role in product choice. The point is that ecological behaviour, promote the maintenance of the environment, to maintain conditions of fair trade etc. are becoming fashionable. Bio products purchase may therefore contribute to the image of responsible consumer. In particular if the customer primarily wishes to give impression it is necessary to be brands are famous. However, the purchase of organic products is still a domain of other organic products producers, patients or mother with small children who have been 
recommended. Current customer buys organic products out of curiosity, of interest to try new things, especially if it is off-price goods.

The modern trends in field of bio products go in this indicate direction. The effort to involve consumers in product building increases. In opposite Instead of usual method of communication typical of conventional foods, organic ones are offered through the experiences and organic products entering the market "with a story" (Václavík, 2008). This allows existing and potential customers to acquire new information, more information and to better known and understand the benefits that organic products offer.

Nowadays grows also the segment of consumers, who want to be "in" and "live bio". These customers mostly do not seek information about bio products and their behaviour is influenced by the opinion leaders. Therefore, it is not surprising that in a study conducted in 2007 in the USA (Onyango, 2007) are typical consumers of bio products women and young people under 32 years.

The offer of functional and emotional benefits for the branding thus will need to design differently depending on the type of the target segment and by specific product type (Orth, 2004).

\section{The Brand Influence to Purchase Decision}

Shopping behaviour is one of the most complex issues of marketing research, because self-determination is essentially invisible. The issue is complicated also by the fact that it is necessary to take into account the effects of consumer, family situation and the particular product (Tomek and Vávrová, 2008).

Effective value offer should lead to the establishment of relationship brand customer and be a driving force behind the decision to buy a product of the brand (Aaker, 2003). The importance of brands for consumers lies in the symbolism of guaranteed quality and provided information, convenience of the customer (product identification, facilitate decision-making, information about the properties of the product) and many other equally important factors (Souček, 2006).

Brand therefore helps to make purchasing decisions and it does not matter whether intuitive or rational decision. In the intuitive decision-making occurs it is subconscious evaluation of many factors (the product, scent, packaging, brand, location in store, as well as current mental state of customer's mind, previous experience with the product and other factors) and ill-considered purchase. Rational decision is an effort to objective assessment of critical factors; a brand theoretically does not belong to this category. In the case that it would be possible to make rational economic decision, i.e. using all relevant criteria and the current evaluation of all available options, the brand should only marginal value. But people do not do economically rational decisions, but they use the administrative model, i.e. search for the first available option in accordance with limited number of criteria. In this model the brand symbolizes a certain quality, price category and image, and thus it is a very important criterion. Thanks to the brand we do not need to verify many difficult observable factors, such as - in the food area - wholesome, quality of materials used as well as taste or appearance and smell of packaged commodities. In 
addition, customers rarely have all necessary information to be able to create rational and objective decision about the quality of the product. Even if they have this information, they usually do not have motivation or time to rationally assess. The result is using one or two incentives, which they consider quality indicators. Regardless of whether in fact they are connected with quality or not (Aaker, 2003).

It need not be just the producer brand. Also the seller brand (private label) creates in many cases certain expectations in the verifiable product attributes and attributes based on confidence. The advent of commercial (retail) brands related to strengthening the role of distributors at the expense of producers. Private labels are more common in bakery and dairy products than e.g. in sweets area (Foret, 2003). In some cases it may not even be a brand of distributor or seller, but only the location of goods in the shop. For example, if an unknown wine brands sold in a recognized wine shop, consumers will probably be considered better quality than if it were sold in the trade type Cash\&Carry. Customers also expected a higher price for the product in the wine shop.

Brand thus subconsciously affects to product expectations. If there is the known quality brand located to inferior food product, customers often declare its high quality (Aaker, 2003). On the other side Jacoby and Mazursky (1984) found that distributing a lower-quality brand in a good reputation store did not improve the brand's image.

This theory does not fully apply in the case of strong brands with long tradition (e.g. Pepsi Cola, Nestlé, Madeta, Danone etc.). These brands will obviously give the same expectation for different distributors, with exception of those which are expected to unfair conduct and sale of counterfeits.

Unlike the counterfeits a lot of customers willing to accept the purchase of imitation strong brand. According to d'Astous and Gargouri (2001) evaluation of product is not influenced of intensity similarity imitation and original, in this case. Customers know that buying an imitation, but particularly in connection with private label they expect good quality at lower costs.

An interesting development can occur in the field of basic foodstuffs, where the brand has not built. The customer does not distinguished too much among different producers of flour, sugar salt, rice, eggs etc. Various quality of these commodities originating from different producers and particularly the efforts of manufacturers to differentiate themselves, however, might imply that there will also build the brands. The first example can be "Vodňanské kuře", chicken producer's brand of poultry and poultry products, which on Czech market gaining considerable knowledge. Producers and distributors of organic food would therefore already count with brand building to distinguish from conventional commodities.

For the most common customers, the organic food market is actually market with unknown products. Such products were purchased by those customers, who already have experience with them or purposefully seek them. Common customer is buying them, because of efforts to try something new, or on the base of the recommendation. In this case he does decision:

- intuitively, based on the first impact (packaging, location, price),

- in accordance with quality symbols, which are identifiable, 
- according to opinion leaders or information from trustworthy data sources,

- according to flysheet or promotive messages.

The price factor is always a crucial and sometimes also the desire to try something new. Consumer can also purchase brand, which he knows of any other kind of product and is satisfied with it or at least he has some specific quality expectation. However according to Lange (2003) a larger number of consumers will choose less typical brands in typical product categories over typical brands in less product categories.

The research on organic food and bio cosmetics, with a sample of 369 people in Mexico suggests, that a good positioning and retailing may extend the customer's perception and to build long term customer value against the unknown brands (Rajagopal, 2007).

In the inquiry, which was performed in 2009 on a sample of 30 students ICT Prague were confirmed the expected main reasons for the purchase of goods unknown brand. Equally important criteria were the recommendation of trustworthy person (14 responses) and the knowledge of important information about the brand on the basis of read or heard (15). Very important factor was the price - discount, invitation event (9). Students absolutely excluded promotion as an important factor to choice of decision (no response) and it was only once mentioned as a reason intuitive decision.

It does not mean, that advertising and intuitive decision-making were negligible. We assume rather that, despite the anonymity of response, it is a tendency to marginalize the influence of promotion and misunderstanding of term intuitive decision. Very often intuitive decision is built on base of opinion leader announcement or on base of previous experience with the product.

The situation can be different if the choice of a product, which is largely determines by sensory aspects. A purchase behaviour research realized in Chinese wine market (it is a new segment, so it is possible to compare it with the organic food market) found that typical consumer in decision-making most preferred criteria previous tasting, wine origin and brand. These criteria are much more important than friends' advice or information on the label or in the shelf of wine (Ying, 2209).

Also in another research (Hes, 2009) the most important factors with influence to customer behaviour were previous experience, price and third one was the brand. Thanks the previous experience customers know which brand the best satisfied their needs and if they next identify it, they can no longer think and receive information (Keller, 2007).

\section{Private labels in Czech retail chains}

According to surveys (Ročenka ..., 2008), most of the Czech consumers buy organic food in retail chains. They have played an important role in promoting organic food thanks to the introduction of its private brands in recent years.

The owner of brand may be not only a producer, under its own brands more and more retailers and other distributors sell goods recently. There are several ways to access the creation of private label. Dealers may sell products under the name of shop, can create an entirely new name or may use their combination. The main advantage of private labels 
is lower price, which are related lower production costs (Keller, 2007). The products, that are in conventional food sector traditionally sold under private labels and are very popular for consumers, include primarily dairy products, vegetables and beverages, while in areas such as cosmetics the development of private labels avoid and the development will not be expected yet.

The introduction of private labels of the organic food products by the large companies related an unprecedented advertising campaign and resulted in an increase in consumption of organic food and in improving knowledge of the organic products' concept among common consumers.

Retail chains offer customers organic food products under their private labels and sell organic food products other brands too. Most of sold organic products are of foreign origin. At the time of introduction of the organic products by the retail chains there were a massive advertising campaign, at the point of sale information leaflets were available and sale was accompanied by the promotion actions or tasting or special favorable organic food packages. Similar actions are organized rather sporadic nowadays. Exception is Interpspar that since 2006 have worked up to its private brand of organic food products SPAR Natur*pur at the forefront of the retail chain. Interspar has for its customers an information leaflet which provides the basic information about organic food. The leaflet is very nice and for many consumers can be a trigger for buying organic food.

The following report shows how the situation looks like in the private labels in the Czech retail chains.

\section{Tesco}

It offers a wide range of organic food products under its private label Tesco Organic. The private label offers more than 100 kinds of products - fruit, vegetables, meat and meat products, dairy products, oils, cereals, pulses, rice, pasta, drinks, wine, tea and coffee, nuts, etc., and range is constantly expanding currently.

The web sites of Tesco present Tesco Organic brand in a separate section where the customer can see all the products offered. Also there is allocated space for information relating to the issue of organic and organic center. Interested persons may also meet directly with the primary producers (links to the organic farm).

\section{Billa}

It offers a wide range of organic foods under its private label naše bio. From here we can find organic fruits and vegetables, milk and dairy products (cow's and goat's milk), oils, cereals, pulses, rice, pasta, beverages, tea, dry fruits and more.

The web sites present naše bio brand in a separate section. There is the possibility to see the full range of offered products, the customer can read about the general facts relating to the organic and there are recipes for preparing meals from the organic food products.

\section{Interspar}

It offers a wide range of organic foods under its private label SPAR Natur * pur. Under this private label are fruits, vegetables, meat and meat products, dairy products, oils, 
cereals, pulses, rice, pasta, drinks, wine, tea and coffee, dry fruits, etc. There are more than 100 items and amount is continuously expanding.

The website present SPAR Natur * pur brand in a separate section. There is the possibility to see the selection of the range of products offered, customers can find general information related to the issue of organic and some tips how to prepare food from the organic food products. Web pages are handled statically not interactive.

\section{Plus}

This type of discount chain offers a range of more than 50 organic foods under its private label BioBio. Here we can find organic fruits and vegetables, milk and dairy products, oils, cereals, pulses, rice, pasta, beverages, tea, dry fruits, spices and more.

There is a separate section of the BioBio brand on the web pages of store. There is the possibility to see the full range of products offered, including detailed information, the customer also can read some basic information about organic.

\section{Dm}

This drugstore started to sell organic products as one of the first store in the Czech Republic. From the beginning there was not its own private label, but than the private label alverde was created and the store offers organic product alverde and certified organic products from the other companies too. Information about the essence of the principles of the organic production and about the offer of organic products customers can find on the web pages.

\section{Coop Družstvo}

Chain offers a wide range of organic foods under its private label Bio COOP. Under this private label we can find fruits, vegetables, meat and meat products, dairy products, oils, cereals, pulses, rice, pasta, drinks, wine, tea and coffee, dry fruits, etc. Between products which are mainly of Czech origin are nearly 50 items and amount is still expanding. COOP Družstvo is proud to the local origin of majority of their organic food products.

There is a separate section on web pages of the store for Bio COOP brand. There is the possibility to see the full range of products offered, including information on prices, the customer also can find the basic information relating to the reasons why to buy organic products.

\section{Albert}

It offers a wide range of organic foods under its private label Albert Bio. At the end of this year promises to sell under this brand 100 products in quality bio. Here we can find organic fruits and vegetables, milk and dairy products, preserves, oils, cereals, pulses, rice, pasta, beverages, tea, dry fruits and more.

There is a separate section on web pages for brand Albert Bio. There is the possibility to see the full range of products offered. For each product we can find comments and experiences of consumers and the entire set of recipes. The customer also can read the basic facts relating to organic and they can know reasons why is better give 
the priority to organic products over conventional products. Pages are user-friendly form processed.

\section{Kaufland}

The chain offers in its range more than 200 products in bio-quality. It did not create its private label, individual products are offered under the producers' brands.

\section{Conclusions}

It is presumable that organic food market will be increasing dynamically in further years. What was used to be not much attractive niche in the food market has become throughout the years - a rapidly growing segment with strong customer base, possessing considerable purchasing power. It is clear that further development of the market will depend not only on the product-diverse range of organic food, but mainly on efficient distribution and communication strategy of companies. A comparison with Western Europe development shows it can be expected to develop new forms of direct distribution, increase organic food supply in the catering and greater dynamism in the retail chains. It seems necessary to implement the strategy of integrated marketing communication, which will lead to building strong and trustworthy brands in the spirit of modern branding.

A suitable way of obtaining conventional foods consumers could be - in particular - using private labels. Consumers know them and have created subconscious anticipation of the quality relation to their price. Young consumers could also be affected by advertisement and opinion leaders or image creators.

An important group of customers could be mothers, who influence the buying habits of the whole of family. Young modern mothers are usually unsatisfied with a single recommendation, but seek more information, so the organic food information should contain the opinions of doctors, dietary specialists, but also data about the composition of foods, their cultivation and other adjustments, etc.

\section{References}

Aaker D.A., Brand building, budování obchodní značky, Computer Press, Brno 2003.

Bohuněk B., I ten nejvěrnějši změni občas dres, „Marketing \&Media“, No. 23, 2009.

D’Astous A., Gargouri E., Consumer evaluations of brand imitations, „European Journal of Marketing“, No. 1/2, 2001.

De Pelsmacker P., Geuens M. Van den Bergh J., Marketingová komunikace, Grada, Praha, 2003.

Fauld D.J. at al., A cross-national investigation of the relationship between the price and quality of consumer products, „Journal of Global Marketing“, No. 1, 1994.

Foret M., Marketingová komunikace, Computer Press, Brno 2003.

Grosová S., Komunikačni strategie nových druhů potravin, „Marketing \& Komunikace“, No.1, 2004.

Grunert K.G. et al., Market Orientation in Food and Agriculture. Kluwer, Boston, MA 1996.

Hes A., Šálková D., Přiklad spotřebitelského chování ve vztahu k obchodním značkám, „Journal of Corporate Management and Economics", No 1, 2009.

Homola M., Vtípil Z., Psychologie trhu a ř́dícich činností, Olomouc: Univerzita Palackého, 1992. 
Jacoby, J., Mazursky, D., Linking brand and retailer images (do the potential risks outweigh the potential benefits?, „Journal of Retailing“, No. 2, 1984.

Keller K.L., Strategické rízeni značky, Grada, Praha 2007.

Kleinová N., Bez loga, Argo, Praha 2005.

Kotler P. Marketing podle Kotlera, Management Press, Praha 2000.

Kotler P., Marketing podle Kotlera, Management Press, Praha 2000.

Koudelka J., Spotřebni chováni a marketing, Grada, Praha 1997.

Krystallis A., Chryssohoidis G., Consumers'willingness to pay for organic food, „British Food Journal“, No. 5, 2005.

Lange F., Selander S., Aberg C., When weaker brands prevail, ,Journal of Product and Brand Management", No. 1, 2003.

Lošt’áková H., Jelínková M., Atributy hodnoty pro zákazníka u produktů určených pro výrobni spotřebu, „Marketing \& Komunikace“, No. 3, 2008.

Nelson P. Information and consumer behaviour, „Journal of Political Economy“, No.78, 1970.

Onyango B.M., Hallman W.K., Bellows A.C., Purchasing organic food in US food systems, „British Food Journal“, No. 5, 2007.

Orth U.R., McDaniel M., Shellhammer T., Lopetcharat K., Promoting brand benefits: the role of consumer psychographics and lifestyle, „Journal of Consumer Marketing“, Nr. 2, 2004.

Padel S., Foster C., Exploring the gap between attitudes and behaviour, Understanding why consumers buy or do not buy organic food. „British Food Journal“, No. 8, 2005.

Parker B.T., A comparison of brand personality and brand user-imagery kongruence. „Journal of Consumer Marketing “, Nr. 3, 2009.

Rajagopal A., Buying decisions towards organic products: an analysis of customer value and brand drivers, „International Journal of Emerging Markets“, No. 3, 2007.

Ročenka Český trh s biopotravinami 2008, Green marketing, 2008.

Souček M., Význam značky, International Scientific Days 2006, Faculty of Economic and Management SAU in Nitra, Nitra, May 17-18, 2006.

Souček M., Význam značky, International Scientific Days 2006, Faculty of Economic and Management SAU in Nitra, Nitra, May 17-18, 2006.

Tomek G., Vávrová V., Jak se rozhoduje zákazník, „Marketing \& Komunikace“, No. 2, 2008.

Tsakiridou E., Boutsouki Ch., Zotos Y., Mattas K., Attitudes and behaviour towards organic products: an exploratory study, „International Journal of Retail \& Distribution Management“, No. 2, 2008, pp. $158-175$.

Václavík T., Marketing biopotravin je novou př́ležitostí, „Marketing \& Média“, No. 12, 2008.

Vysekalová J., Psychologie spotřebitele, Grada Publishing, Praha 2004.

Ying Yu et al., Chinese choices: a survey of wine Wine consumers in Beijing. „International Journal of Wine Business Research“, No. 2, 2009.

http://www.itesco.cz/organic/, 1.11.2009

http://www.nasebio.cz/, 1.11.2009

http://www.interspar.cz/spar/SPAR_znacky/Spar_Natur_pur.htm, 1.11.2009

http://www.mze.cz/s 


\section{Aspekty rozwoju "private label" w segmencie artykułów żywnościowych w Republice Czeskiej}

\section{Streszczenie}

$W$ artykule przedstawiono zróżnicowane aspekty rozwoju , private labels” stosowanych $w$ segmencie sprzedaży artykułów żywnościowych $w$ Republice Czeskiej. Szczególna uwaga została poświęcona tworzeniu ,,private labels” oraz procesom podejmowania decyzji konsumenckich $w$ wyborze tak oznaczonych produktów. Na końcu artykułu zwrócono uwage na bariery rozwoju ,private labels” w Czechach. 